\title{
Giant coronary arterial aneurysm after drug-eluting stent implantation
}

\author{
Akshyaya Pradhan, ${ }^{1}$ Akhil Kumar Sharma, ${ }^{1}$ Nirdesh Jain, ${ }^{2}$ Sharad Chandra Yadav ${ }^{1}$
}

${ }^{1}$ Department of Cardiology, King George's Medical University, Lucknow, Uttar Pradesh, India 2Department of Internal Medicine, CSMMU (earlier KGMU), Lucknow, Uttar Pradesh, India

\section{Correspondence to} Dr Nirdesh Jain, nirdeshjain8@gmail.com

Accepted 16 March 2016

\section{DESCRIPTION}

A 55-year-old man with diabetes, a smoker, presented with acute coronary syndrome (ACS). Coronary angiogram revealed single vessel disease in the proximal left anterior descending (LAD) artery (figure 1 and video 1 ), which was treated with a drug-eluting stent (video 2). The patient had been asymptomatic for 4 months, when he was again admitted with ACS. Coronary angiogram (Integris H5000, Philips) showed a giant coronary artery aneurysm (CAA) in the proximal LAD artery with restenosis (figure 2) where the drug-eluting stent had been implanted. The patient was sent for coronary artery bypass surgery.

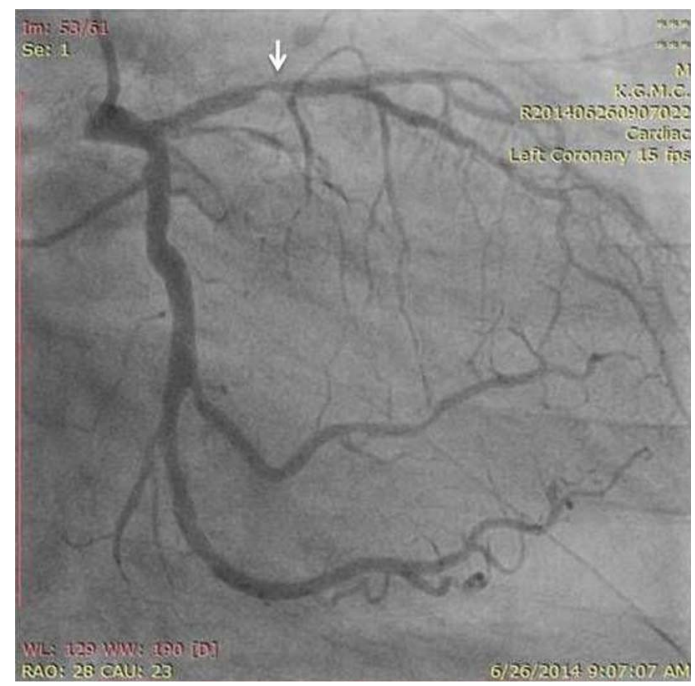

Figure 1 Coronary angiogram, right anterior oblique caudal view, showing severe stenosis in the proximal left anterior descending artery (white arrow).

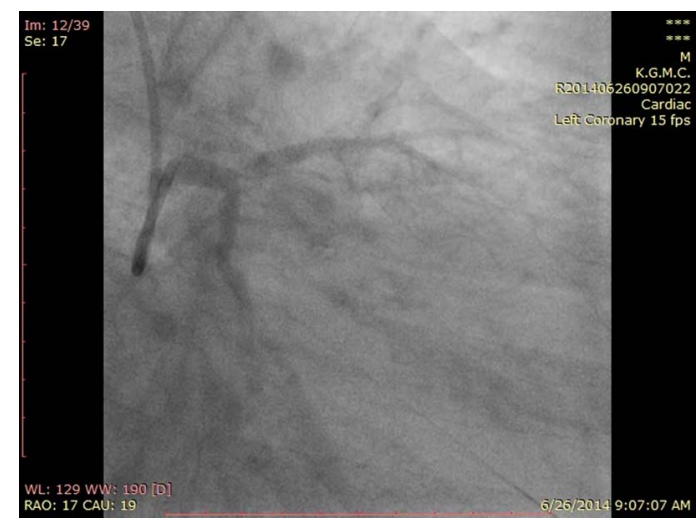

Sharma AK, Jain N, et al BMJ Case Rep Published online: [please include Day Month Year] doi:10.1136/ bcr-2016-214488

CrossMark
Video 1 Coronary angiogram, right anterior oblique caudal view, showing severe stenosis in the proximal left anterior descending artery.
CAAs after coronary interventions, the complication is not widely known by coronary interventionist because of its very rare occurrence. ${ }^{1}$ Small CAAs are frequently unrecognised incidental findings in patients with coronary artery disease. Giant aneurysm has been defined as when the maximal diameter exceeds $20 \mathrm{~mm}$ in adults or $8 \mathrm{~mm}$ in children. It was encountered for the first time at a high volume, tertiary care centre in north India offering coronary interventions. We report here an image of giant CAA. The precise mechanism for CAA remains unknown. A few hypotheses have been postulated, such as extensive vessel injury during the initial procedure, hypersensitivity reactions, infectious processes and malappositions. ${ }^{2}$

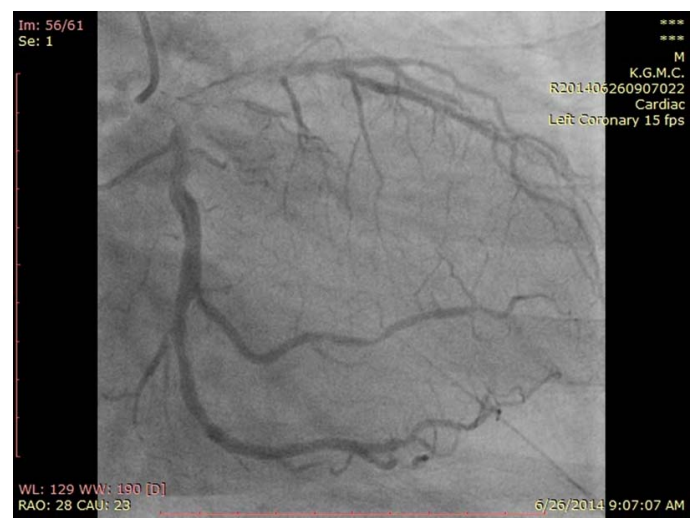

Video 2 Coronary angiogram, right anterior oblique caudal view, showing percutaneous angioplasty with stenting of the proximal left anterior descending artery.

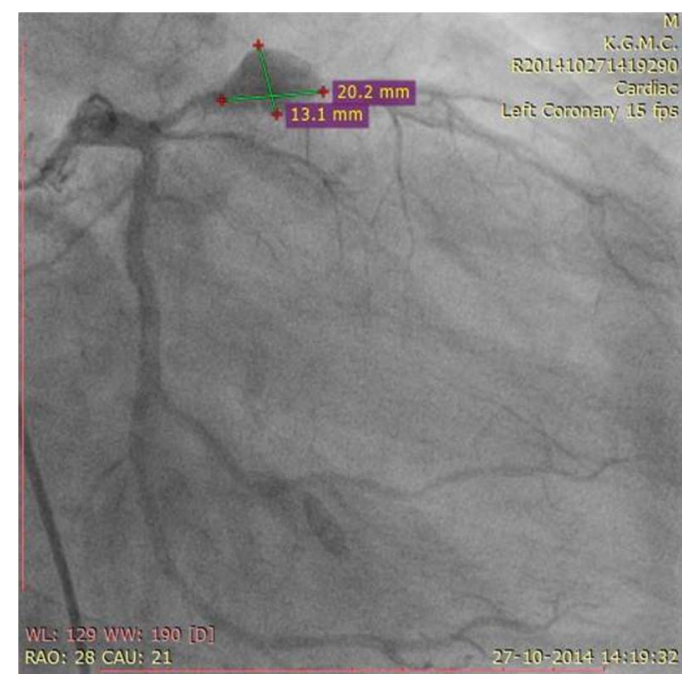

Figure 2 Coronary angiogram showing giant coronary artery aneurysm at the same location where the stent was placed 4 months prior. 
The giant CAA may be incidentally detected in echocardiography, though coronary angiography is required to make an accurate diagnosis of this entity. Intravascular ultrasound imaging is important to delineate anatomical details, which further helps in management.

\section{Learning points}

- Giant coronary artery aneurysm may develop in a short period of months after a drug-eluting stent implantation and may present as acute coronary syndrome.

- Coronary interventionists should be aware of this very rare entity.
CAA mostly remains asymptomatic but may also present with systemic infections after coronary intervention, angina and ACS. Treatment options are conservative, covered stent placement, coil embolisation and surgical procedures.

Contributors AP was involved in conception of the study. AKS and NJ contributed by drafting the manuscript. All the authors reviewed the manuscript.

Competing interests None declared.

\section{Patient consent Obtained.}

Provenance and peer review Not commissioned; externally peer reviewed.

\section{REFERENCES}

1 Aoki J, Kirtane A, Leon MB, et al. Coronary artery aneurysm after drug-eluting stent implantation. JACC Cardiovasc Interv 2008;1:14-21.

2 Alfonso F, Pe'rez-Vizcayno MJ, Ruiz M, et al. Coronary aneurysms after drug-eluting stent implantation: clinical, angiographic, and intravascular ultrasound findings. I Am Coll Cardiol 2009;53:2053-60.

Copyright 2016 BMJ Publishing Group. All rights reserved. For permission to reuse any of this content visit http://group.bmj.com/group/rights-licensing/permissions.

BMJ Case Report Fellows may re-use this article for personal use and teaching without any further permission.

Become a Fellow of BMJ Case Reports today and you can:

- Submit as many cases as you like

- Enjoy fast sympathetic peer review and rapid publication of accepted articles

- Access all the published articles

- Re-use any of the published material for personal use and teaching without further permission

For information on Institutional Fellowships contact consortiasales@bmjgroup.com

Visit casereports.bmj.com for more articles like this and to become a Fellow 